\title{
Determination of In-Vitro Anticancer Activity and Short Chain Fatty Acids in Traditionally Fermented Millet Gruels
}

\author{
P. Praveen Kumar ${ }^{1 *}$ and V. Hazeena Begum² \\ ${ }^{1}$ Research Scholar, Department of Siddha Medicine, Faculty of Science, Tamil University, Thanjavur-613 010, India \\ ${ }^{2}$ Professor \& Head, Department of Siddha Medicine, Faculty of Science, Tamil University, Thanjavur-613 010, India
}

Corresponding author: pravee.21msc@gmail.com

\begin{abstract}
The millets are called as nutricereals due to the availability of beneficial nutrients. The fermented millet gruels prepared from P. miliare, S. italica, P. scrobiculatum and E. frumantacea. and the millet gruels were analysed for the Short chain fatty acids (SCFA). The anticancer efficacy of the fermented millet gruels also investigated in vitro in the Human breast cancer cell line, MCF-7. P. miliare fermented gruel showed the acetic acid in the levels of $0.89 \mu \mathrm{M}$, lactic acid as $1.76 \mu \mathrm{M}$, propionic acid in the levels of $1.82 \mu \mathrm{M}$ and butyric acids in the levels of $10.58 \mu \mathrm{M}$. The fermented S.italica gruel showed acetic, lactic and butyric acid levels of $1.12 \mu \mathrm{M}, 2.41 \mu \mathrm{M}$ and $42.85 \mu \mathrm{M}$ respectively. The fermented P.scrobiculatum gruel showed the acetic acid of $1.04 \mu \mathrm{M}$, lactic acid of $0.89 \mu \mathrm{M}$, proponic acid of $2.26 \mu \mathrm{M}$ and butyric acid of $3.09 \mu \mathrm{M}$. The fermented $E$. frumantacea also showed high levels of propionic acid $(8.93 \mu \mathrm{M})$ and $2.7 \mu \mathrm{M}$ of acetic acid. The anticancer efficacy also shown the $S$. italica fermented gruel have the high potential against the breast cancer cell line, MCF-7 compared to the other fermented millet gruel. It may be due to the high butyric acid content of the $S$. italica fermented gruel.
\end{abstract}

Keywords: Millets, SCFA, anticancer activity, Butyric acid, MCF-7

Millet is more than just an interesting alternative to the more common grains. The grain is also rich in phytochemicals, including phytic acid, which is believed to lower cholesterol, and phytate, which is associated with reduced cancer risk (Coulibaly et al. 2011). These health benefits have been partly attributed to the wide variety of potential chemopreventive substances, called phytochemicals, including antioxidants present in high amounts in foods such as millets (Izadi et al. 2012).

Breast cancer is now the most common cancer in Indian women, having recently overtaken cervical cancer in this respect. Earlier cervical cancer was most common cancer in Indian woman but now the incidence of breast cancer has surpassed cervical cancer and is leading cause of cancer death, although cervical cancer still remains most common in rural India (Kaarthigeyan, 2012).

Fermentation involves in the production of many nutraceutical products such as Short chain fatty acids (SCFA), antimicrobial agents, vitamins, etc. The fermentation of millets also produce many nutrients which will combat against many disorders. Millet's whole grain also shows prebiotic activity, which helps to increase the population of friendly bacteria that plays a key role to promote digestion. Malting induces important beneficial biochemical changes in the millet grain.

How to cite this article: P. Praveen Kumar and V. Hazeena Begum (2020). Determination of In-Vitro Anticancer Activity and Short Chain Fatty Acids in Traditionally Fermented Millet Gruels. Intl. J. Ferment. Food, 9(2): 31-35.

Source of Support: ICMR, New Delhi; Conflict of Interest: None (क) 9 
In the present study we are interested in searching food products which may reduce the severity of the deadly disorders such as breast cancer. Since the anticancer drugs are not afforded by many of the people in our country, a food source which could control the cancer severity will be beneficial to the poor people in India. The present study was carried out to investigate anticancer efficacy of the fermented minor millets against human breast cancer cell lines.

\section{MATERIALS AND METHODS}

\section{Preparation of fermented millet gruel}

$20 \mathrm{~g}$ of the millet grains were cleaned and washed with potable water. $100 \mathrm{ml}$ of potable water was added and cooked well. Cooked meal was cooled to room temperature and $150 \mathrm{ml}$ of water was added. The mixture was fermented for overnight and the gruel was analyzed for propionic acid content by high performance thin layer chromatography (HPTLC) technique. The 1.0-ml fermented gruels were centrifuged for $5 \mathrm{~min}$ at $5000 \mathrm{~g}$. The resulting supernatants were then transferred to an eppendorf tube to perform the identification process of acetic, propionic, lactic and butyric acids. Prior to use, the samples were filtered through $0.45 \mu \mathrm{m}$ filter.

\section{Determination of SCFA by HPTLC}

A Camag HPTLC system equipped with an automatic TLC sampler, TLC scanner 3 and integrated software WINCATS version 1.4.1 was used for the analysis. Chromatrography was performed on $10 \mathrm{~cm} \times 10 \mathrm{~cm}$ HPTLC plates coated with silica gel 60F 254 (E-Merck) of $200 \mu \mathrm{m}$ layer thickness for the quantification of propionic acid. Standard and samples were applied to the plates as $8 \mathrm{~mm}$ long bands, $8 \mathrm{~mm}$ apart by use of a Camag Linomat(V) sample applicator equipped with a $10 \mu \mathrm{l}$ microsyringe and an automatic TLC sampler under a flow of Nitrogen gas.

The linear ascending development was carried out in a Camag glass twin through chamber $(20 \mathrm{~cm} \times 10$ $\mathrm{cm})$ previously saturated with $20 \mathrm{~mL}$ mobile phase containing acetone: water: chloroform: ethanol: ammonium hydroxide (60:2:6:10:22) mixture (Lee et al., 2001) for $15 \mathrm{~min}$ at room temperature $25^{\circ} \mathrm{C}$. Plates were developed to a distance of $80 \mathrm{~mm}$. Subsequent to the development; the TLC plate was dried in a current of air with an air dryer. The TLC plates were then removed from the chamber and allowed to dry in air. The dried TLC plates were sprayed with the indicator solution, and the color was developed by brief heating (1-3 min.) in a hot dry oven $165^{\circ} \mathrm{C}$. Quantitative evaluation of the plate was performed in absorbance-reflectance mode at $\lambda_{\max }=210 \mathrm{~nm}$, using a slit width $6 \times 0.4 \mathrm{~mm}$, data resolution 100 mm Step - 1, scanning speed $20 \mathrm{mms}^{-1}$ and baseline correction was used.

\section{In vitro anticancer activity}

\section{Preparation of fermented millet gruel extract}

The millets were cooked and cooled to room temperature. The cooked millets were added with $100 \mathrm{ml}$ of potable water and fermented for overnight. The fermented gruels were extracted with Petroleum ether and Diethyl ether (1:1) and the solvents are evaporated and dried. The residues were reconstituted in DMSO for the in vitro anticancer assay.

\section{Cell culture conditions}

MCF-7 human breast carcinoma cell line was purchased from National Center for Cell Sciences (NCCS), Pune. The cell lines were grown at $37^{\circ} \mathrm{C}$ in a $5 \% \mathrm{CO}_{2^{\prime}}$ 95\% air humidified atmosphere, in DMEM supplemented with $10 \%$ heat inactivated Fetal Bovine Serum (FBS) to which penicillin $(100 \mathrm{U} / \mathrm{mL})$ and streptomycin $(100 \mu \mathrm{g} g / \mathrm{ml})$ had been added. $\mu / \mathrm{mL})$ and amphotericin B (5 The growth-inhibitory effect of L-glutaminase (freeze dried dialysed fractions) on the cancer cell lines was determined using a colorimetric test, MTT assay.

Cells were seeded in 96-well plates at a density of $5 \times 10^{3}$ cells per well in $100 \mu \mathrm{l}$ of medium with FBS then cultured in a $\mathrm{CO}_{2}$ incubator at $37^{\circ} \mathrm{C}$ for $24 \mathrm{~h}$. After which, $10 \mu \mathrm{l}$ of fermented millet gruels (or 20 $\mu l$ of DMEM medium with FBS for the control) was added to each well and the plate was incubated for 
$96 \mathrm{~h}$. After incubation, $20 \mu \mathrm{l}$ MTT stock solution (5 $\mathrm{mg} / \mathrm{ml}$ in phosphate buffered saline or PBS, $\mathrm{pH}$ 7.5, filtered through $0.22-\mu \mathrm{m}$ cellulose acetate filter; Sigma, St. Louis) was added to each well, incubated for $4 \mathrm{~h}$ at $37^{\circ} \mathrm{C}$ then the solution was decanted. To stop succinate tetrazolium reductase activity and solubilise formazan crystals, $100 \mu \mathrm{L}$ of propanol was then added to each well. Absorbance was read on a plate reader (VERS Amax, Molecular Devices, Saint Gregoire, France) at $540 \mathrm{~nm}$. The percentage growth inhibition was calculated using the following formula and the concentration of enzyme extract needed to inhibit cell growth by $50 \%$ (CTC50) values is generated from the dose response curves for each cell line.

\section{RESULTS AND DISCUSSION}

\section{SCFA Analysis by HPTLC}

The fermented millet gruels showed different concentrations of short chain fatty acids such as acetic, propionic, butyric and lactic acids (Table 1). P. miliare fermented gruel showed the acetic acid in the levels of $0.89 \mu \mathrm{M}$, lactic acid as $1.76 \mu \mathrm{M}$, propionic acid in the levels of $1.82 \mu \mathrm{M}$ and butyric acids in the levels of $10.58 \mu \mathrm{M}$. The fermented S.italica gruel showed acetic, lactic and butyric acid levels of $1.12 \mu \mathrm{M}, 2.41$ $\mu \mathrm{M}$ and $42.85 \mu \mathrm{M}$ respectively. The fermented $P$. scrobiculatum gruel showed the acetic acid of $1.04 \mu \mathrm{M}$, lactic acid of $0.89 \mu \mathrm{M}$, proponic acid of $2.26 \mu \mathrm{M}$ and butyric acid of $3.09 \mu \mathrm{M}$. The fermented E.frumantacea also showed high levels of propionic acid $(8.93 \mu \mathrm{M})$ and $2.7 \mu \mathrm{M}$ of acetic acid.

\section{In-vitro anticancer activity}

The effect of extracellular and intracellular extracts on the viability of cancer cells was determined by MTT (3[4, 5-dimethylthiazol-2-yl]-2, 5-diphenyltetrazolium bromide) assay on HeLa cells. The most active extracts were further screened on MCF-7 cells by MTT assay. The viability of the MCF-7 cells were determined by exposing cells to various concentrations of the fermented millet gruel $(0.31 \mathrm{mg} / \mathrm{mL}, 0.62 \mathrm{mg} / \mathrm{mL}$, $1.25 \mathrm{mg} / \mathrm{mL}$ and $2.5 \mathrm{mg} / \mathrm{mL}$ ) for $72 \mathrm{~h}$. The viability $\%$ was defined as the concentration of drug at which there was $50 \%$ less growth compared to control cells. Each experiment was performed in triplicate and is shown in the Tab (Fig. 1 to 4).

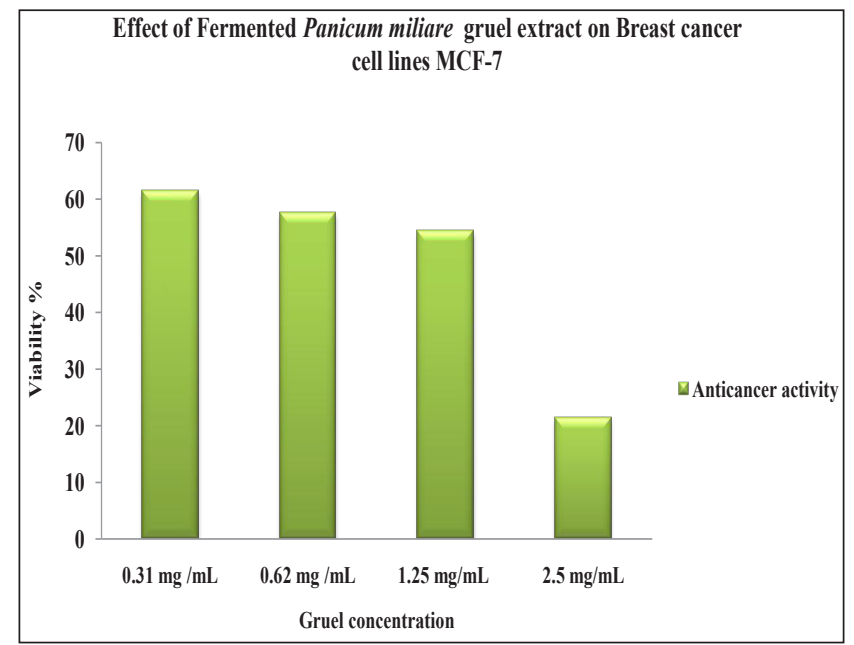

Fig. 1: Effect of Fermented Panicum miliare gruel extract on Breast cancer cell lines MCF-7

Results indicated that the extracts of Setaria italica fermented gruel and Panicum miliare gruels had promising anticancer activity against Breast cancer (MCF-7) cell lines. The S.italica gruel at a concentration of $2.5 \mathrm{mg} / \mathrm{mL}$ showed only $15.54 \%$ of growth compared to control on MCF-7 cells by the MTT method. The S. itailica extract showed $55.08 \%$

Table 1: SCFA content of fermented millet gruels by HPTLC

\begin{tabular}{lllll}
\hline SCFA $(\mu \mathrm{M})$ & $\begin{array}{l}\text { Panicum miliare } \\
\text { (Samai) }\end{array}$ & $\begin{array}{l}\text { Setaria italica } \\
\text { (Thinai) }\end{array}$ & $\begin{array}{l}\text { Paspalum scrobiculatum } \\
\text { (Varagu) }\end{array}$ & $\begin{array}{l}\text { Echinochloa frumantacea } \\
\text { (Kudiraivali) }\end{array}$ \\
\hline Acetic acid & $0.89 \pm 0.25$ & $1.12 \pm 0.73$ & $1.04 \pm 0.54$ & $2.7 \pm 1.14$ \\
Lactic acid & $1.76 \pm 0.69$ & $2.41 \pm 0.76$ & $0.89 \pm 0.77$ & $0.7 \pm 0.71$ \\
Propionic acid & $1.82 \pm 0.82$ & $\mathrm{NA}$ & $2.26 \pm 0.91$ & $8.93 \pm 0.42$ \\
Butyric acid & $10.58 \pm 0.67$ & $42.85 \pm 1.10$ & $3.09 \pm 1.05$ & $5.64 \pm 0.36$ \\
\hline
\end{tabular}


growth of MCF-7 cells at the initial concentration of $0.31 \mathrm{mg} / \mathrm{mL}$ and it gradually reduced to $15.54 \%$ growth which is more potential concentration of the drug against the MCF-7 breast cancer cell lines.

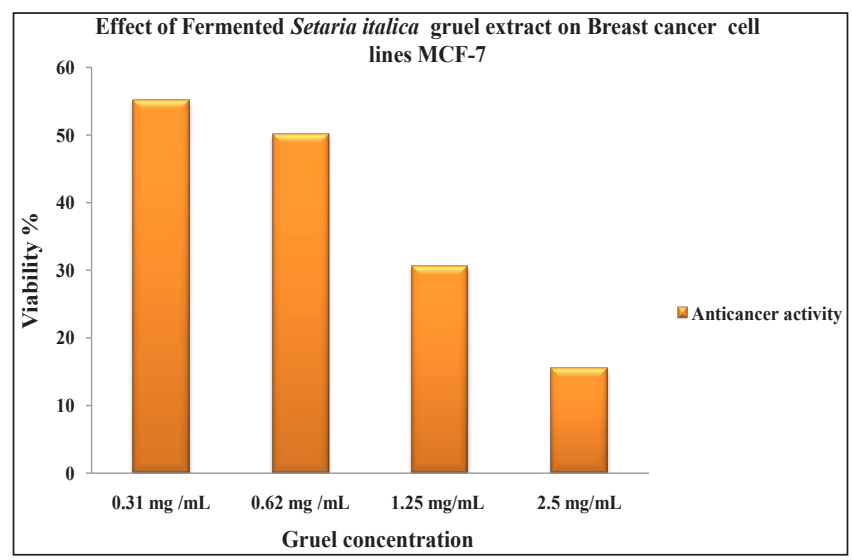

Fig. 2: Effect of Fermented Setaria italica gruel extract on Breast cancer cell lines MCF-7

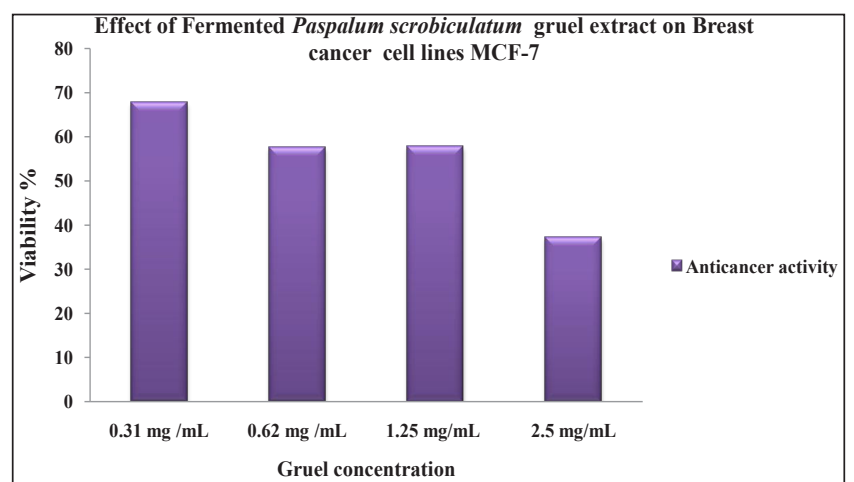

Fig. 3: Effect of Fermented Paspalum scrobiculatum gruel extract on Breast cancer cell lines MCF-7

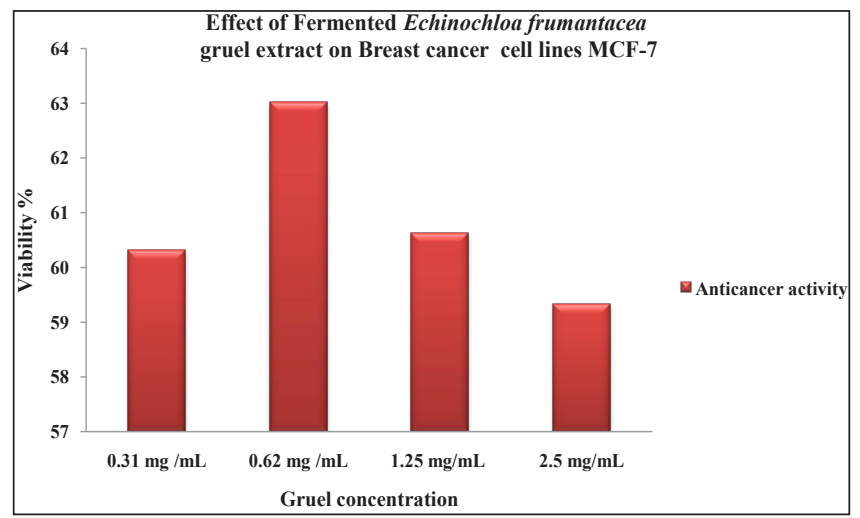

Fig. 4: Effect of Fermented Echinochloa frumantacea gruel extract on Breast cancer cell lines MCF-7
Panicum miliare extract showed the inhibition of the growth of breast cancer cells at the concentration of $21.34 \%$ at the maximum of dosage of $2.5 \mathrm{mg} / \mathrm{mL}$ and the maximum viability of the cancer cells were observed at the concentration of $0.31 \mathrm{mg} / \mathrm{mL}$ concentration of the millet gruel extract. The P. scrobiculatum showed only $67.69 \%$ of inhibition of the MCF-7 cell lines at the concentration of $0.31 \mathrm{~g} / \mathrm{mL}$ and it showed $37.28 \%$ growth at the maximum concentration of $2.5 \mathrm{~g} / \mathrm{mL}$, which is comparatively lower than the $P$. miliare and S. italica fermented gruel extracts.

The E. frumentace fermented gruel extract has not shown significant reduction in the growth of breast cancer cell line MCF-7 at the concentrations from $0.31 \mathrm{mg} / \mathrm{mL}$ to $2.5 \mathrm{mg} / \mathrm{mL}$. It showed the growth of the cancer cells from $59.32 \%$ to $60.31 \%$ which were significantly lower than the other fermented millet gruels. The $S$. italica showed more anticancer efficacy compared to other fermented gruels. It showed more butyric acid content of $42.85 \mu \mathrm{M}$. The high anticancer activity of $S$. italica fermented gruel may be the high contribution of butyric acid content.

In vivo studies have associated butyrate levels with a decreased incidence of colon cancer (Mcintyre et al. 1993; Okata et al. 1989), and butyrate instilled into the colonic lumen reduced tumor production in a chemical model of colon carcinogenesis (Medina et al. 1988). Although its precise mechanisms of action are not well understood, butyrate inhibits histone deacetylase (HDAC), resulting in a relative hyperacetylation of core histone proteins ( $\mathrm{H} 3$ and H4) (Sealy \& Chalkley, 1978).

\section{REFERENCES}

Augeron, C. and Laboisse, C.L. 1984. Emergence of permanently differentiated cell clones in a human colonic cancer cell line after treatment with sodium butyrate. Cancer Res., 44: 3961-3969.

Coulibaly, A., Kouakou, B. and Chen, J. 2011. Phytic acid in cereal grains: structure, healthy or harmful ways to reduce phytic acid in cereal grains and their effects on nutritional quality. Am. J. Plant Nutr. Fert. Technol., 1: 1-22.

Izadi, Z., Nasirpour, A., Izadi, M. and Izadi, T. 2012. Reducing blood cholesterol by a healthy diet. Int. Food Res. J., 19(1): 29-37. 
Kaarthigeyan, K. 2012. Cervical cancer in India and HPV vaccination. Indian J. Med. Paediatr. Oncol., 33: 7-12.

Lee, K.Y., So. J.S. and Heo, T.H. 2001. Thin layer chromatographic determination of organic acids for rapid identification of bifidobacteria at genus level. J Microbiol. Meth., 45: 1-6.

Mcintyre, A., Gibson, P.R. and Young, G.P. 1993. Butyrate production from dietary fiber and protection against large bowel cancer in a rat model. Gut., 34: 386-391.

Medina, V., Afonso, J.J., Alvarez-Arguelles, H., Hernandez, C. and Gonzalez, F. 1988. Sodium butyrate inhibits carcinoma development in a 1,2- dimethylhydrazine-induced rat colon cancer. J. Parenter. Enteral. Nutr., 22: 14-17.
Okata, M., Singhal, A. and Hakomori, S. 1989. Antibodymediated targeting of differentiation inducers to tumor cells: inhibition of colonic cancer cell growth in vivo and in vitro. Biochem. Biophys. Res. Commun., 158: 202-208.

Sealy, L. and Chalkley, R. 1978. The effect of sodium butyrate on histone modification. Cell, 14: 115-121.

Whitehead, R.H., Young, G.P. and Bhathal, P.S. 1986. Effects of short chain fatty acids on a new human colon carcinoma cell line (LIM 1215). Gut., 27: 1457-1463. 
